\title{
Preliminary surveys after release of the fruit fly parasitoid Fopius arisanus Sonan (Hymenoptera Braconidae) in mango production systems in Casamance (Senegal)
}

\author{
Ousmane Ndiaye $^{1 \star}$, Saliou Ndiaye ${ }^{2}$, Saliou Djiba ${ }^{3}$, Cheikh Tidiane Ba ${ }^{4}$, Larry Vaughan ${ }^{5}$, Jean-Yves Rey ${ }^{6}$ \\ and Jean-François Vayssières ${ }^{7}$ \\ 1 Écologie et gestion des écosystèmes, ED-SEV/UCAD, BP 115 Thiès, Sénégal \\ 2 École nationale supérieure d'agriculture, Université de Thiès, BP A 296 Thiès, Senegal, \\ 3 Institut sénégalais de recherches agricoles/Djibélor Ziguinchor, Sénégal \\ 4 Département biologie animale, FST, UCAD, Dakar Senegal \\ 5 Integrated Pest Management Collaborative Research Support Program, Office of International Research, Education and Development \\ 526 Prices Fork Road (0378) Virginia Tech Blacksburg, VA 24061 USA \\ 6 CIRAD-Persyst, UPR HortSys, ISRA/CDH, BP 484, Thiès, Sénégal \\ 7 CIRAD-Persyst, UPR HortSys, IITA, Biological Control Unit for Africa 08 BP 0932, Cotonou, Benin
}

Received 9 April 2014 - Accepted 27 December 2014

\begin{abstract}
Introduction. Since its arrival in Senegal in 2004, Bactrocera invadens (Diptera Tephritidae) synonymized with Bactrocera dorsalis has caused much economic damage in mango crops. Effective and efficient control activities against $B$. invadens were necessary in order to continue mango production, and biological control measures were envisaged. In such conditions, the government of Senegal allowed the Asian parasitoid Fopius arisanus to be released in some orchards around Ziguinchor. Materials and methods. The dynamics of fruit fly species was studied with lure traps (methyl eugenol and terpinyl acetate with Dichlorvos). Mango fruit were sampled from the control orchard and orchards with released $F$. arisanus, to compare the differences in tephritid infestation. Results and discussion. The levels of B. invadens populations were 1.6-2.5 times higher in the control than in orchards where F. arisanus was released. The fruit were also 5-6 times more infested in the control orchard than in those that received $F$. arisanus. Between May and July 2012 the majority of the pupae (92\%) collected from fruit samples developed into adult flies, while only $39 \%$ of the pupae transformed to adults between October and December after effective action of the parasitoids. In both orchard treatments, the level of native fruit fly populations was about the same. Wild fruit were infested mostly by Ceratitis cosyra, from which were reared native parasitoids such as Fopius caudatus, F. silvestrii, F. desideratus, Diachasmimorpha fullawayi, D. carinata, Psyttalia cosyrae, and P. concolor. In contrast with Mangifera indica, Citrus spp., Anacardium occidentale, Psidium guayava, Saba senegalensis, and Landolphia heudelotii were mainly infested by $B$. invadens which showed parasitism by $F$. arisanus. Pteromalidae and Eulophidae were also found from the pest fly pupae. Killer flies (Diptera: Muscidae) such as Coenosia attenuata Stein, C. atra Meigen and C. tigrina Fabricius emerged from the fruit samples. Conclusion. Sanitation against fruit flies in Casamance should take into account the conservation of natural enemies such as parasitoids and predators for an effective biological control of tephritids.
\end{abstract}

Keywords: Senegal / Casamance / Mangifera indica / mango / fruit fly / Bactrocera invadens / Fopius arisanus / biological control

Résumé - Enquêtes préliminaires après lâcher du parasitoïde de la mouche des fruits Fopius arisanus Sonan (Hyménoptère, Braconidae) dans des plantations de manguiers en Casamance (Sénégal). Introduction. Depuis son introduction au Sénégal en 2004, Bactrocera invadens (Diptère, Tephritidae) synonyme de Bactrocera dorsalis, a causé d'énormes dégâts économiques aux cultures de manguiers. Des mesures réelles et efficaces de lutte contre B. invadens se sont avérées indispensables pour continuer à produire des mangues, et des méthodes de lutte biologique ont été envisagées. Dans ces conditions, le gouvernement du Sénégal a autorisé l'importation du parasitoïde asiatique Fopius arisanus afin de le lâcher dans quelques vergers autour de Ziguinchor. Matériel et méthodes. La dynamique des espèces de mouche des fruits a été étudiée à partir de pièges attractifs (à base de méthyle d'eugénol et d'acétate de terpinyle associés au Dichlorvos). Les mangues ont été échantillonnées à partir d'un verger témoin et de vergers dans

^ Corresponding author: ousmanen@outlook.fr 
lesquels a été lâché $F$. arisanus, afin de comparer les taux d'infestation en téphritides. Résultats et discussion. Les populations de $B$. invadens ont été dénombrées 1,6 à 2,5 fois supérieures dans le verger témoin par rapport aux vergers où F. arisanus a été lâché. Les fruits en provenance du verger témoin étaient également 5 à 6 fois plus infestés que ceux des vergers traités. Entre mai et juillet 2012 la majorité des pupes collectées (92\%) à partir des fruits échantillonnés ont développé de mouches adultes, tandis qu'entre octobre et décembre seulement $39 \%$ des pupes se sont transformées, suite à l'action des parasitoïdes. Dans les deux types de verger, le niveau des populations natives de mouches des fruits s'est montré sensiblement le même. Les fruits d'espèces sauvages ont principalement été infestés par la mouche Ceratitis cosyra, de laquelle ont émergé plusieurs parasitoïdes natifs tels Fopius caudatus, F. silvestrii, F. desideratus, Diachasmimorpha fullawayi, D. carinata, Psyttalia cosyrae, et $P$. concolor. En revanche, les fruits de Mangifera indica, Citrus spp., Anacardium occidentale, Psidium guayava, Saba senegalensis, et Landolphia heudelotii étaient principalement infestés par B. invadens dont les pupes ont également révélé les parasites F. arisanus. Pteromalidae et Eulophidae. Les mouches tueuses (Diptère, Muscidae) telles que Coenosia attenuata Stein, C. atra Meigen et $C$. tigrina Fabricius ont émergé des échantillons de fruits. Conclusion. L'assainissement de la Casamance contre les mouches des fruits devrait prendre en compte la conservation des ennemis naturels tels que parasitoïdes et prédateurs pour un contrôle biologique efficace des téphritides.

Mots clés : Sénégal / Casamance / Mangifera indica / mangue / mouche des fruits / Bactrocera invadens / Fopius arisanus / lutte biologique

\section{Introduction}

Bactrocera invadens (Drew et al.) synonymized with Bactrocera dorsalis [1] and Ceratitis cosyra (Walker) (Diptera: Tephritidae) are the principal pests of economic importance in mango production in the Niayes [2] and Casamance areas of Senegal $[3,4]$. In Casamance famers are not accustomed to use chemicals to control pests, and losses are up to $80 \%$ instead of $30-50 \%$ in the Niayes. The parasitoid diversity [4] showed more environmental and sanitary benefits from biological control in this area where people treated the nature respectfully. Studies undertaken from 2008 to 2012 in mango orchards of the Niayes, the Plateau of Thiès and Casamance showed that $B$. invadens severely attacked 30 mango varieties, 18 citrus species ( 21 cultivars) and many other host plants such as Achras sapota L., Anacardium occidentale L., Annona muricata L., Annona senegalensis Pers., Carica papaya L., Capparis tomentosa Lam., Chrysobalanus orbicularis Sch., Cordyla pinnata (Lepr.) Miln.-Red., Diopyros mespiliformis Hochst., Eugenia uniflora L., Ziziphus mauritiana Lam., Psidium guajava Radd., Kedrostis hirtella (Naud.) Cogn., Phoenix dactylifera L., Sclerocarya birrea (A.Rich.) Hochst., Icacina senegalensis A.Juss., Landolphia dulcis (R.Br.) Pichon., L. heudelotii A. DC., L. florida Benth., Lannea acida A. Rich., Saba senegalensis (A.DC.) Pichon., Sarcocephalus latifolius (Smith) Bruce, Spondias mombin L., Uvaria chamea P. Beauv. and Ximenia americana L. With such a broad range of hosts, B. invadens was rapidly more abundant than native fruit flies such as Bactrocera cucurbitae (Coquillett), Dacus sp., Ceratitis silvestrii Bezzi, C. capitata (Wiedemann) C. fasciventris De Meyer C. bremii GuérinMéneville, C. punctata (Wiedemann), C. quinaria (Bezzi), Carpomyia sp. and Capparimyia bipustulata (Bezzi) [2] .

Community dynamics in orchards showed that $B$. invadens was more abundant than Ceratitis cosyra, $C$. bremii, $C$. silvestrii, $C$. punctata, $C$. quinaria and $C$. fasciventris. Within these orchards, most of the indigenous and weed plants hosted fruit flies. In those orchard fruit, tephritids were parasitized by indigenous braconids such as Fopius caudatus (Szépligeti),
F. silvestri (Wharton), F. desideratus (Bridwell), Diachasmimorpha fullawayi (Silvestri), D. carinata (Szépligeti), Psyttalia cosyrae (Wilkinson) and P. concolor (Szépligeti) [4]. $F$. caudatus was the most abundant wasp, and the native parasitoids showed a greater preference for $C$. cosyra than for $B$. invadens [3]. The same behavior was found by Vayssières et al. [5] in Benin, where $F$. caudatus was the most important parasitoid reared from fruit infested mostly by C. cosyra. $B$. invadens was not substantially parasitized by these parasitoids.

In only four years, $B$. invadens spread over 8.3 million $\mathrm{km}^{2}$ covering 28 countries of West, Central, and East Africa including rainforest ecosystems and savannas with 117 host plants from 43 families [6]. African ecosystems do not have an indigenous parasitoid that can effectively control B. invadens, but co-evolved parasitoids of this invasive pest were found in Sri Lanka where the invader fly originated. These parasitoids include Braconidae species [Diachasmimorpha longicaudata (Ashmead), Psyttalia incisi (Silvestri), Fopius arisanus Sonan, Fopius sp.]; Eulophidae (Tetrastichus sp.); Pteromalidae (Spalangia sp.) and Diapriidae (Trichopria sp.) (Mohamed et al. unpubl.; Billah et al. unpubl.). Quimio and Walter [7] reported that $F$. arisanus prefered mostly Bactrocera tryoni Froggart and B. jarvisi Tryon rather than B. cucumis French. Moreover $F$. arisanus showed a preference for $B$. invadens over C. capitata, C. cosyra, C. rosa Karsch, C. fasciventris, and $C$. anonae Graham [8]. After the introduction of $F$. arisanus in Hawaii in 1946 it became the most abundant parasitoid controlling the invasive tephritids $[9,10]$. Therefore, in 2011 the government of Senegal authorized imports of $F$. arisanus for biological control of $B$. invadens. The first releases were done in 2011, in mango orchards in Casamance where this study was carried out. This work evaluates the preliminary effect of F. arisanus release on major mango tephritid pests. Secondly, it evaluates the competitive effects of $F$. arisanus release on native parasitoids. Finally, it aims to identify other fly species such as Muscidae Coenosia that develop in fruit besides tephritid flies. 


\section{Materials and methods}

Orchards in Casamance differ from the orchards in the Niayes. There are few export-oriented plantations; rather most of the orchards are small scale and dedicated to the local market. These traditional orchards are planted with mango, cashew and citrus and receive little or no maintenance. Traditional orchards are often bounded by hedges of Jatropha curcas L., Euphorbia balsamifera Ait., Dichrostachys cinerea (L.) Wight \& Arn., Eucalyptus sp., and Mezoneureum benthamianum Baill. Infrequent weed clearance encourages wild fruit species such as A. senegalensis, I. senegalensis, Sorindeia juglandifolia (A. Rich.) Planch. ex Oliv., L. dulcis, L. florida, L. heudelotii, L. acida, S. senegalensis, S. latifolius, S. mombin, U. chamea, and $X$. americana. In these traditional orchards the density of some wild fruit species is often higher than the cultivated crops (mango, cashew or citrus) [2]. Our study focused on these traditional plots.

In total 5,000 wasps of $F$. arisanus reared from IITA/Benin were released in each of three orchards in June 2012. A fourth orchard located $30 \mathrm{~km}$ away from the nearest release orchard, did not receive any release of this parasitoid (control). As with most of the orchards in Casamance, the chosen farms were 1 to 2 ha in size planted with mango, cashew and citrus, and were surrounded by forest. After a six-month baseline survey in Casamance in April-September 2010 [4] investigations were pursued from September 2011 to September 2012 to evaluate the effect of Fopius arisanus releases A weekly survey of the fruit fly populations was done in the four orchards using two kinds of traps at each location: i) semiochemical lure traps [Tephritraps with methyl eugenol + DDVP (2, 2 Dichlorovinyl dimethyl-phosphate) and terpinyl acetate + DDVP] [11] and, ii) food lure traps [Tephritraps with water and a food attractant such as Torula] were used in each orchard. A total of 2,509 fruits $(148.4 \mathrm{~kg})$ were collected from trees and on the ground under these trees inside and around the four orchards 1,254 fruits before and 1,255 fruits after the release dates.

Sampling was performed over a full year to cover the fruiting seasons of the major host plants in order to collect information on the whole range of fruit flies and parasitoids from each fruit species. Fruit samples were returned to the laboratory of ISRA/Djibelor, Senegal. In the sampling areas available mature fruit of cultivated (mango, citrus, cashew...) and wild species at prematurity and mature (ripe) stages were randomly sampled on a weekly basis. Plant species were determined using the flora guide of West African dry zones [12,13] and that of Senegal [14]. Fruit fly species were determined using insect identification keys $[15,17]$ and results were confirmed by Vayssières et al. [5]. Parasitoid identifications were done by Wharton [4] at Texas A\&M University (USA).

Data on fruit fly infestation rate, parasitism rate, parasitoid species and abundance were recorded. Percentage parasitism was calculated as $\frac{a}{a+b} \times 100$, where $a=$ number of emerged parasitoids, and $b=$ number of emerged adult flies in each sample [4]. Analysis of variance was performed using the general linear model procedure and mean separations were done using the Fisher test, normality and KHI 2 tests were used (SAS 2003) [18]. A principal component analysis was performed for interactions among fruit flies and parasitoids. A Shannon index of biodiversity was estimated for each host plant using $D_{S p}=\sum_{i=1}^{n}-p_{i} \ln \left(p_{i}\right)$, with: $\mathrm{D}_{\mathrm{Sp}}=$ biodiversity index; each orchard or host plant $\mathrm{i}$ was associated $P_{i}=n_{\mathrm{i}} / N$ with $n_{\mathrm{i}}=$ the number of insects (Tephritidae, Muscidae and Braconidae) emerged from the orchard or host plant i, and $N=$ the total individuals for this insect.

\section{Results}

\subsection{Fruit fly dynamics in the orchards}

Fruit flies were trapped from January to August in the four orchards. In the traps $B$. invadens was always the most abundant fruit fly species (figure 1) compared to native species such as $C$. cosyra, $C$. silvestrii, $C$. bremii, C. punctata, $C$. quinaria and $C$. fasciventris. The same phenomenon was found in the rainy season (June-October) with the Tephritraps using water and Torula as food attractant: B. invadens (83\%) was more abundant than $C$. cosyra (12\%), C. capitata $(2.8 \%)$, C. silvestrii $(1.1 \%)$, C. fasciventris $(0.1 \%)$. At peak periods $B$. invadens was 1.6-2.5 times more abundant in the control orchard than in the farms where $F$. arisanus was released. The $B$. invadens level decreased one week after releases, while its populations continued to increase in the control orchard. The abundance of native flies remained roughly the same in all orchards. It was confirmed by the non-attendance of significant difference between the diversity indexes in the orchard $P=0.067$ (figure 2). Among these native flies, $C$. cosyra was the most abundant. The size of $C$. silvestrii population was more important in the dry season (November-May) than the rainy season, in contrast with $C$. bremii and $C$. punctata.

The diversity of fruit flies trapped was analyzed in the four orchards. The diversity index of fruit fly species has been computed for each orchard (figure 2). This index was found to vary from one orchard to another with no relation to parasitoid release. Such variability was mostly due to the composition in host plants in the orchard. Orchard 2 had the smallest peak of fruit fly population but had the greatest diversity among the trapped fruit flies. Orchard 1 and the control had diversity index values above the mean (1.9) of all orchards. Among the three treated orchards two had a biodiversity index lower than the control. Although the control orchard had an index value of biodiversity just above the average its infestation by $B$. invadens was the highest. Thus it seems that the population size of $B$. invadens was not linked to the biodiversity in the orchard. Other factors should play a role such as the diversity of cultivated and wild host plants in the orchard and the frequency of cultural maintenance

\subsection{Fruit infestation in release orchards}

From the 2,509 sampled fruits of the study, about half of them (1,259 fruits) were infested by fruit flies, and $68 \%$ of these infested fruits were collected before release. A number of 23,663 pupae were reared from these infested fruits, of which $61 \%$ were Tephritidae, $10 \%$ were Braconid parasitoids, and $1 \%$ Eulophidae or Pteromalidae. Flies such as Muscidae 

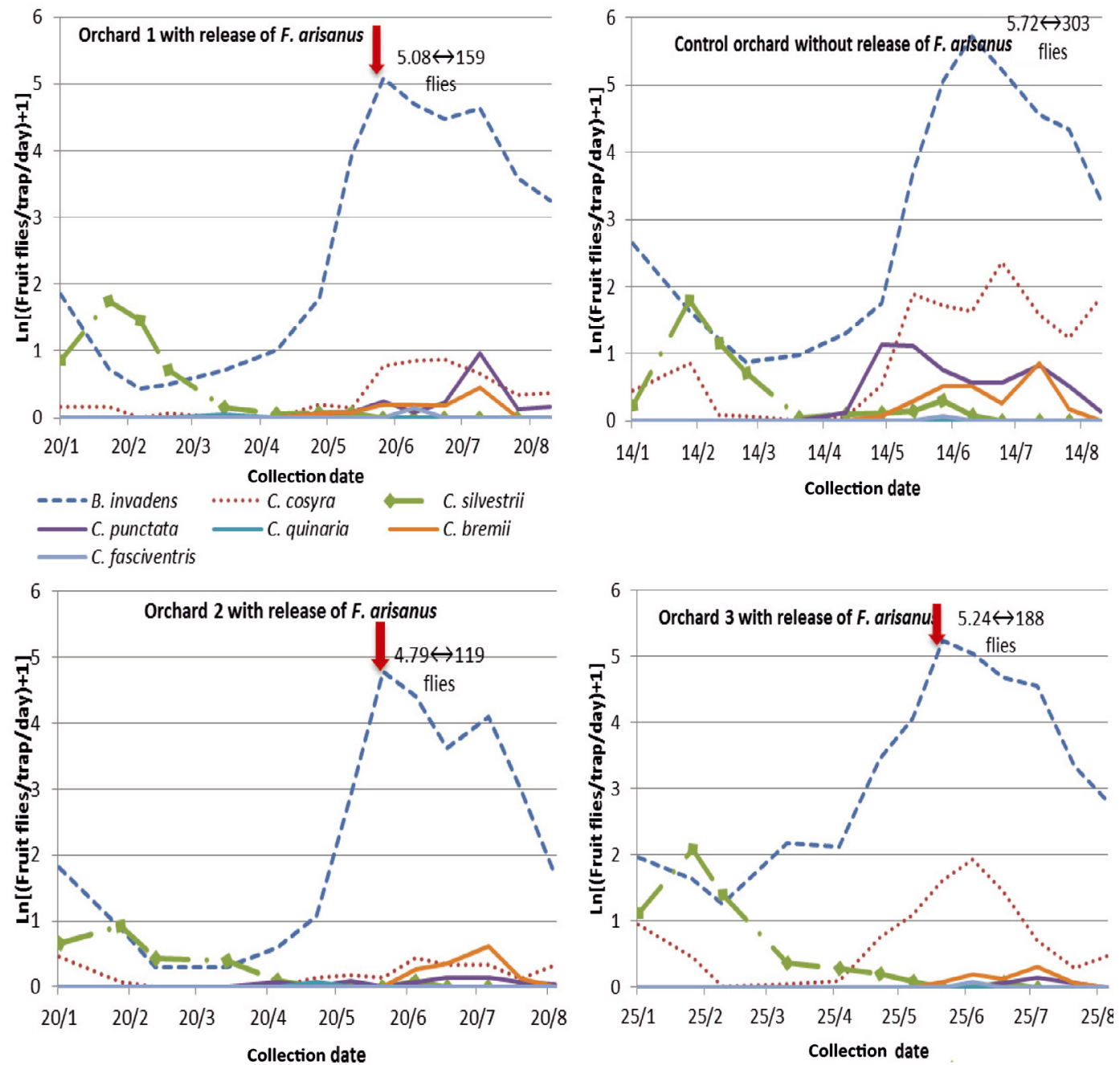

Figure 1. Fluctuation of fruit fly populations in orchards before and after F. arisanus release in 2012 (Release date is shown by the vertical arrow).

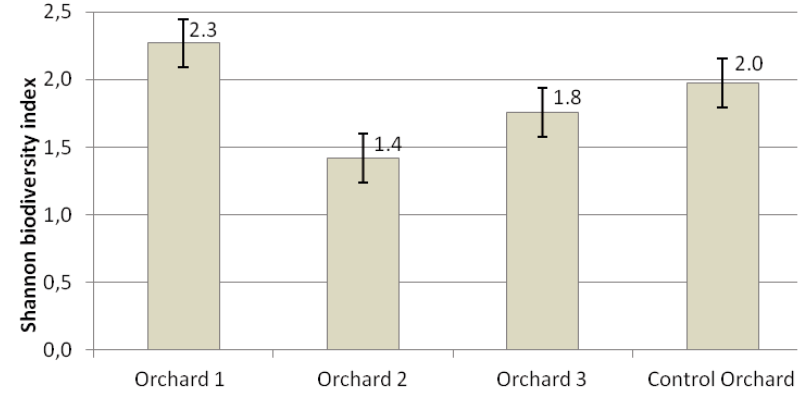

Figure 2. Biodiversity in the studied orchards (Fisher's test: $P=$ $0.067, n=14$ collecting dates per orchard).

were also reared from the fruit samples. The fruits regularly sampled allowed us to study the dynamics of the tephritids and braconids per $\mathrm{kg}$ (figure 3 ).

From the fruit sampling two periods could be distinguished with peak infestations (figure 3). From May to August all fruit were infested with $92 \%$ of the pupa yielding fruit flies, while from September to January only $39 \%$ of the pupa yielded fruit flies. After a high record of parasitoid emergence, most of the pupae $(61 \%)$ did not yield flies. The fruit fly emergence is low from September to February and from February to May fruit are rare in the orchards and surrounding forests.

With the first fruit available in April, infestation by fruit flies started to increase. From June to July more than $92 \%$ of pupae yielded fruit flies. At the same time the braconid populations increased and became more important between July and September (figure 3). When they became adult, these parasitoids were effective biocontrol agents that developed within fruit fly eggs and larvae, thus reducing considerably the pest emergence between November and December. If one would consider a whole year, the wasp fluctuation should follow a normal distribution with a peak between July and September $\left(\right.$ for alpha $=0.05 ; p$-value $=0.600 ; \mathrm{JB}_{\text {(Observed Value })}=$ $1.021 ; \mathrm{JB}_{\text {(Critical Value })}=5.991 ; \mathrm{df}=2$; and the risk to reject $\mathrm{H}_{0}$ whereas it is true up to $60.03 \%$ ). Fruit were significantly more infested in the control orchard than in orchards where $F$. arisanus was released $(P=0.006, r=0.76)$ (figure 4$)$. 


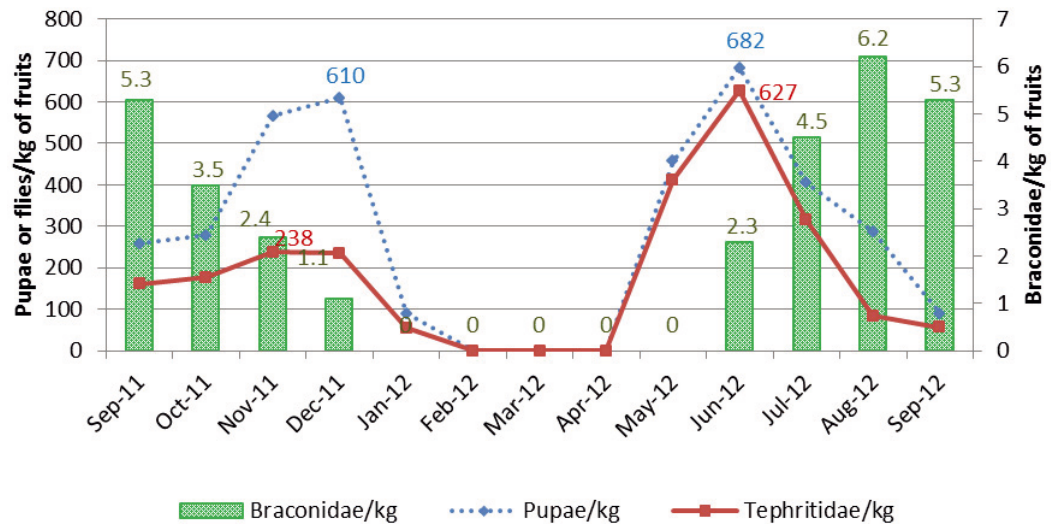

Figure 3. Fluctuation of pupae, reared fruit flies and Braconidae per mass of fruit infested in 2012.

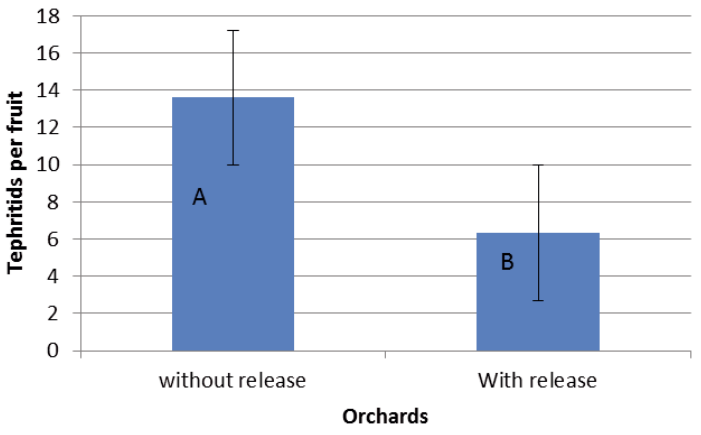

Figure 4. Pest flies emerging per fruit from orchards with and without $F$. arisanus release (data from 2012, LSD-value $=2.26$, Fischer's test: $P=0.006, n=1,259$ fruits $)$.

\subsection{Fruit flies and parasitoids according to host plants}

Whenever the orchard received $F$. arisanus release or not, fruit were mostly infested by the same pests: $B$. invadens, $C$. cosyra, C. silvestrii and $C$. punctata. From these fruit, the emerging procession of parasitoids was enriched by F. arisanus, which started to reproduce in the orchards in addition to the indigenous species: $F$. caudatus, $F$. silvestrii, $F$. desideratus, $D$. fullawayi, $D$. carinata, $P$. cosyrae and $P$. concolor. Other parasitoids belonging to the Pteromalidae and Eulophidae were reared from fruit fly pupae in these fruit samples.

A principal components analysis of these data was carried out, taking into account the $F$. arisanus release effects (figure 5). On the F1-axis, wild plants had fruit infested mainly by flies like $C$. cosyra, $C$. silvestrii and $C$. punctata. These wild plants included A. senegalensis, S. latifolius, I. senegalensis and $L$. dulcis. In their fruit, the native tephritids were parasitized mostly by native braconids such as $F$. caudatus, $F$. silvestrii, F. desideratus, D. fullawayi, D. carinata, P. cosyrae, $P$. concolor and a few wasps from Pteromalidae and Eulophidae. All these wasps were dominated by $F$. caudatus and host parasitoids seemed to control the pests significantly.

On the other hand, the F2-axis showed cultivated and wild plants of which most have economic importance (figure 5). This group of plants including $M$. indica, Citrus sp., A. occidentale, $P$. guayava, $S$. senegalensis and
$L$. heudelotii, were mainly infested by $B$. invadens that was mainly parasitized by $F$. arisanus. Wasps of Pteromalidae and Eulophidae were reared from pupae of $B$. invadens and Ceratitis species. The most infested host plants also produced fruit for a long period in the field: 9 months for S. latifolius, 7 months for $M$. indica and A. occidentale, 4 months for $L$. dulcis and A. senegalensis, and 3 months for I. senegalensis.

\subsection{Killer flies (Muscidae) found in fruit samples}

In addition to the tephritid pests and their parasitoids in the Braconidae, Eulophidae and Pteromalidae some adults of killer flies were found from the pupae received from fruit samples. These killer flies or hunter flies (genus Coenosia Meigen (Muscidae: Coenosiinae)) included Coenosia attenuata Stein, $C$ atra Meigen, and $C$ tigrina Fabricius. Based on the host fruit from which fruit fly and killer fly pupae were collected a matrix of correlation was established (table I). On the one hand fruit flies like $C$. cosyra and $C$. silvestrii were highly correlated each other $(r=0.925)$. On the other hand they were both correlated to the killer fly $C$ tigrina ( $r=0.786$ and 0.731 resp.). The two other killer flies $C$ attenuata $(r=0.794)$ and $C$ atra $(r=0.570)$ emerged mostly from fruit infested by $B$ invadens.

Muscidae and Tephritidae were also assessed through the host plants from which they emerged (figure 6). This principal component analysis was based on six host plants infested by flies such as B. invadens, $C$. cosyra, $C$. silvestrii and $C$. punctata. Sarcocephalus latifolius was mostly infested by the pest $C$. cosyra and $C$. silvestrii and by the predator $C$ tigrina. Psidium guayava was mostly infested by the pest $B$. invadens and the predator $C$ attenuata and $C$ atra. Next to the presence of hunter flies, we can note an important diversity of insects in the sampled fruits many of them infested by tephritid and killer flies. Considering all these insects, the biodiversity index per host plant was fluctuating (table II) indicating the main diversity of pest, parasitoids and killer flies was issued from the fruit Plants mostly infested by fruit flies such as A. senegalensis $S$. latifolius, I. senegalensis, M. indica, L. dulcis and P. guayava had more abundant parasitoids and killer flies. Consequently plants most infested by pest flies also contained high number of parasitoids and predators such as hunter flies for natural biological control. For example from an overall of 755 fruits 


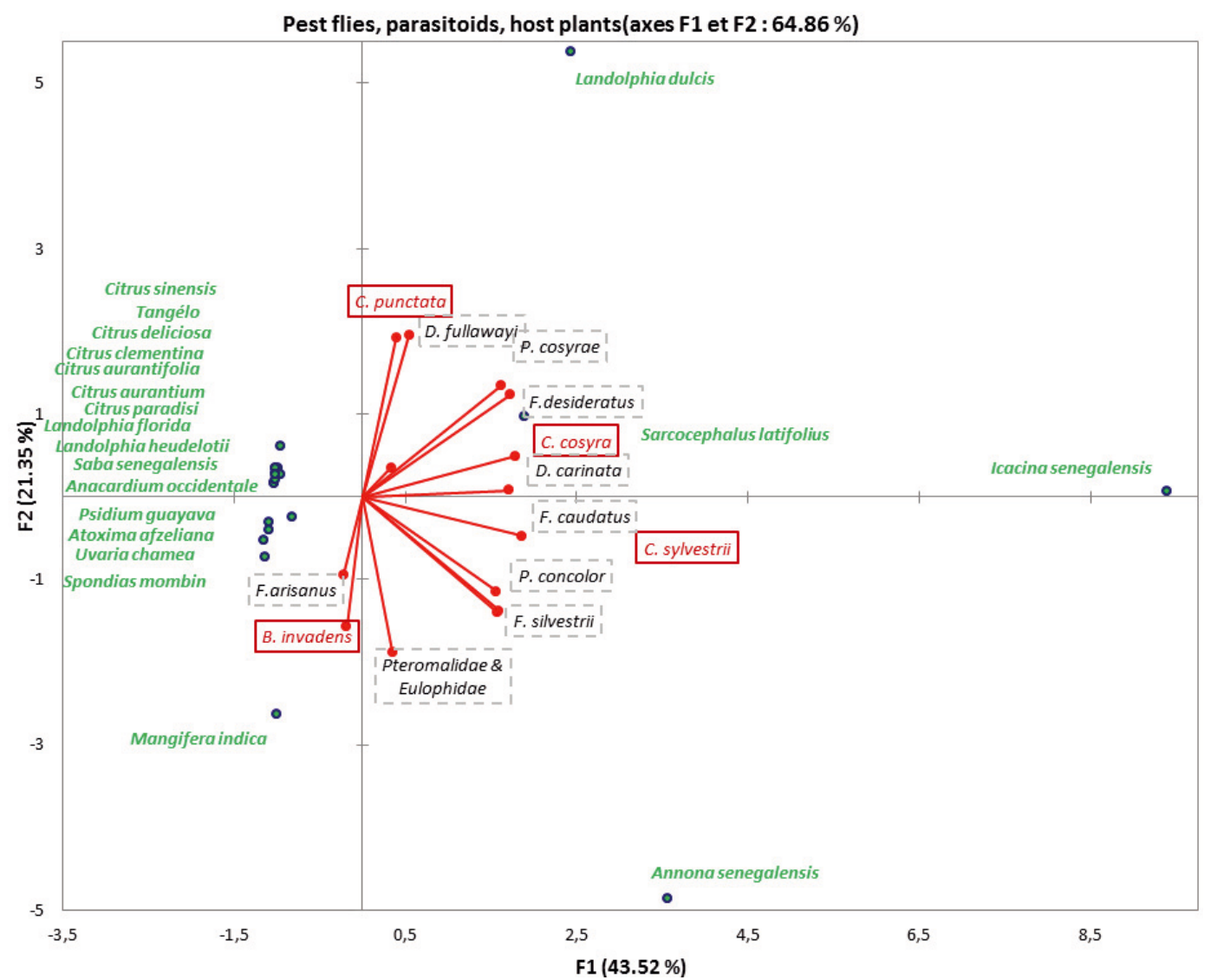

Figure 5. Distribution of the pests (in red) and their parasitoids (in black) through the host plants (in green) (data from the 2012 survey). Axis F2 mostly explains the contributions of two pest flies B. invadens and $C$. punctata and 2 braconids $F$. arisanus and $D$. fullawayi while the other braconids and the 2 pest flies $C$. cosyra and $C$. silvestrii contributed to axis F1.

Table I. Matrix of correlation (Pearson (n)) between fruit flies and killer fly. Figures in bold are significant $(P<0.05)$.

\begin{tabular}{lccccccc}
\hline & $\begin{array}{c}\text { Bactrocera } \\
\text { invadens }\end{array}$ & $\begin{array}{c}\text { Ceratitis } \\
\text { cosyra }\end{array}$ & $\begin{array}{c}\text { Ceratitis } \\
\text { silvestrii }\end{array}$ & $\begin{array}{c}\text { Ceratitis } \\
\text { punctata }\end{array}$ & $\begin{array}{c}\text { Coenosia } \\
\text { attenuata }\end{array}$ & $\begin{array}{c}\text { Coenosia } \\
\text { tigrina }\end{array}$ & $\begin{array}{c}\text { Coenosia } \\
\text { atra }\end{array}$ \\
\hline Bactrocera invadens & $\mathbf{1}$ & & & & & & \\
Ceratitis cosyra & 0.039 & $\mathbf{1}$ & & & & & \\
Ceratitis silvestrii & -0.172 & $\mathbf{0 . 9 2 5}$ & $\mathbf{1}$ & & & & \\
Ceratitis punctata & -0.329 & -0.333 & -0.200 & $\mathbf{1}$ & & & \\
Coenosia attenuata & $\mathbf{0 . 7 9 4}$ & 0.305 & -0.001 & -0.252 & $\mathbf{1}$ & & $\mathbf{1}$ \\
Coenosia tigrina & -0.369 & $\mathbf{0 . 7 8 6}$ & $\mathbf{0 . 7 3 1}$ & -0.306 & -0.132 & $\mathbf{1}$ \\
Coenosia atra & $\mathbf{0 . 5 7 0}$ & 0.025 & 0.014 & $\mathbf{- 0 . 7 4 6}$ & 0.307 & -0.293 & $\mathbf{1}$ \\
\hline
\end{tabular}

sampled on S. latifolius, 18,304 pupae were collected. From these pupae $54 \%$ were fruit flies $B$. invadens $(1 \%)$, C. cosyra (98\%), C. punctata (1\%) and $11 \%$ were parasitoids $90 \%$ of which were $F$. caudatus.

\section{Discussion}

In our results fruit flies were more abundant in the orchards without release of $F$. arisanus than orchards where this wasp was released. This dynamic was mainly due to the abundant flies yielded by infested fruit in orchards without release. Fruit samples from orchards that received the released wasps were less infested and yielded less abundant flies. The important number of fruit species and their long period of production (from 3 to 9 months) contribute to increase the tephritid populations in the orchards. In addition famers aren't accustomed to use chemical to control pest. Therefore the uses of parasitoids that fight naturally against the invader fly are more beneficial. These preliminary results of these inoculative releases seem promising. It encouraged the government to reinforce this activity to achieve a level such as exhibited by Harris et al. [19] who got a decrease of pest fly populations 23 times less after release than before. This decrease is clear with the populations of $B$. invadens, which is the species preferred by $F$. arisanus according to Mohamed et al. [8].

The most abundant native parasitoid ( $F$. caudatus) exclusively parasitizes Ceratitis MacLeay [20,24]. We found 


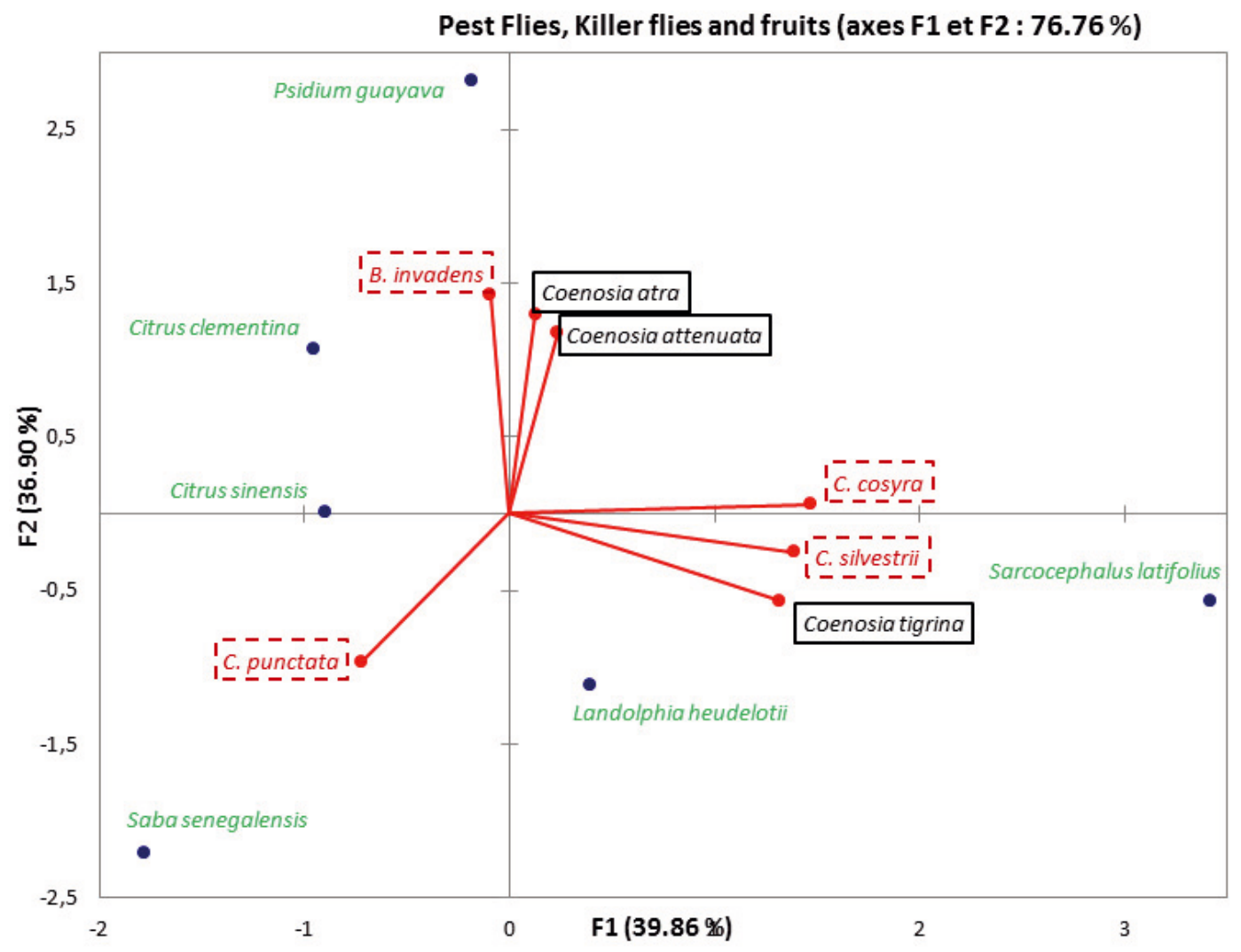

Figure 6. Distribution of pest flies (red dotted box) and killer flies (in black plain box) through their host plants (green spot). B. invadens and Killer flies such as $C$. atra and $C$. attenuata contributed mostly to hold axis $\mathrm{F} 2$ while pest flies like $C$. cosyra and $C$. silvestrii and the killer $C$. tigrina contributed to axis F1.

Table II. Diversity of insects (pest flies, parasitoids and killer flies) found in a range of fruit trees present in or around the studied orchards.

\begin{tabular}{lcc}
\hline Fruit tree species & $\begin{array}{c}\text { Shanon diversity index } \\
\sum-\mathrm{pi} \ln (\mathrm{pi})\end{array}$ & $\begin{array}{c}\text { Standard } \\
\text { Error }\end{array}$ \\
\hline Anacardium occidentale & 0.50 & 0.02 \\
Annona senegalensis & 3.30 & 0.03 \\
Citrus aurantifolia & 0.20 & 0.01 \\
Citrus clementina & 0.60 & 0.03 \\
Citrus sinensis & 0.40 & 0.02 \\
Ficus sur & 0.30 & 0.02 \\
Icacina senegalensis & 2.20 & 0.02 \\
Landolphia dulcis & 1.60 & 0.03 \\
Landolphia florida & 0.50 & 0.02 \\
Landolphia heudelotii & 0.90 & 0.02 \\
Mangifera indica & 2.10 & 0.04 \\
Psidium guayava & 1.30 & 0.03 \\
Saba senegalensis & 0.60 & 0.02 \\
Sarcocephalus latifolius & 3.20 & 0.03 \\
Spondias mombin & 0.50 & 0.02 \\
Uvaria chamea & 0.10 & 0.03 \\
Ximenia americana & 0.20 & 0.02 \\
\hline
\end{tabular}

this wasp mostly in fruit infested by C. cosyra. F. caudatus, F. arisanus and $F$. ceratitivorus that are egg-pupal parasitoids, attack hosts in the earliest stages [20-23]. They are more competitive than those that parasitize flies in later stages. All the 6 other wasps were shown to be larval-pupal parasitoids. Psyttalia cosyrae is a larval-pupal parasitoid $[25,26]$ that attacks $C$. cosyra in mango and wild fruit $[27,28]$ as well as several species belonging to Bactrocera dorsalis complex. Psyttalia concolor parasitizes the second and last larval stages of Ceratitis capitata [29,30]. Its hosts include other fruit flies such as Ceratitis, Capparimyia, Carpomya, and Dacus ones [31]. F. silvestrii infests C. capitata, and Dacus bivittatus $[24,32]$ while $F$. desideratus infests flies from the genera of Ceratitis and Dacus. D. carinata infests species of Ceratitis and Bactrocera Macquart while D. fullawayi parasitizes several species of Ceratitis such as C. capitata [20]. All these native parasitoids contribute to maintain native fruit flies at low levels compared to the invader fly. The fruit fly biological control was reinforced by the action of $F$. arisanus in the orchards where it was released. In our results, F. caudatus preferred species of Ceratitis such as $C$. cosyra, $C$. sylvestrii, $C$. punctata while $F$. arisanus preferred mostly $B$. invadens. The preference for $B$. invadens instead of Ceratitis species like C. capitata, C. cosyra, C. rosa Karsch, C. fasciventris, and C. anonae Graham was reported by Mohamed et al. [8]. It is based on the hypothesis that after the release in the orchard, the females quickly explore and parasitize fruit fly eggs in mango [33]. Beside mango, F. arisanus tracked mostly B. invadens in its wide host range including Citrus spp., Psidium guayava, Spondias mombin, Anacardium occidentale and 
Saba senegalensis. These results confirmed those obtained by Eitam and Vargas [34] who mentioned a parasitism rate from 41 to $72 \%$ of Bactrocera dorsalis by F. arisanus in the fruit of Psidium cattleianum Sabine, P. guajava, and Terminalia catappa L. In Kenya, Ekesi [35] obtained a parasitism rate in mango of up to $40 \%$ of B. invadens in the field. F. arisanus could also parasitize $C$. capitata, $C$. cosyra and $C$. anonae [8]. This wasp was reported as polyphagous parasitoid infesting 40 host flies [36-43]. Finally $F$. arisanus prefers $B$. invadens while $F$. caudatus prefers $C$. cosyra and $C$. silvestrii and this provides more confidence for the biological control of our major mango pest flies $B$. invadens and $C$. cosyra $[2,4]$. The control included the action of the gregarious parasitoids like Pteromalidae and Eulophidae as shown before by Vayssières et al. [4] in the same area.

The correlations established between these killer flies (Coenosia attenuata, C. tigrina and C. atra) and the pest flies (B. invadens, $C$. cosyra and C. punctata) seemed to promise some potential of biological control. Additional experiments need to be done for more information.

\section{Conclusion}

Fruit heavily infested by fruit flies received naturally more parasitoids and predators. Consequently sanitation activities in orchards must take into account all biological agents including parasitoids and generalist predators. Among generalist predators killer flies and weaver ants have to be taken into account since they are also useful biological control agents [44]. As the first major mango pest (C. cosyra) is parasitized by an eggattacking wasp ( $F$. caudatus) combined with others during the larval stages, the releases have to combine the egg-pupal parasitoid ( $F$. arisanus) with other larval-pupal parasitoids such as $D$. longicaudata and $D$. incisi to control B. invadens at its different stages.

Acknowledgements. Our studies were carried out at the Institut Sénégalais de Recherches Agricoles of Ziguinchor. We would like to express our thanks to the Ecole Doctorale des Sciences de la vie de l'Environnement et de la Santé, to the Direction des Parcs Nationaux, the Integrated Pest Management Collaborative Research Support Program/USAID, to Kémo Badji at the Direction de la Protection des Végétaux and to the Projet d'Appui au Développement Economique et de Reconstruction de la Casamance for grant support. The International Institute of Tropical Agriculture (IITA), the Centre de Coopération Internationale en Recherche Agronomique pour le Développement (CIRAD) are gratefully acknowledged. Dr R.A. Wharton (Texas AgriLife Research Award Number 0949027) is acknowledged for his helpful identifications.

\section{References}

[1] Schutze M. K., Khalid Mahmood, Pavasovic A., Newman W. J., Clarke A. R., Krosch M., Cameron S. L. One and the same: integrative taxonomic evidence that Bactrocera invadens (Diptera: Tephritidae) is the same species as the Oriental fruit fly Bactrocera dorsalis. The Royal Entomological Society, Systematic Entomology 2014.
[2] Ndiaye O., Vayssières J.-F., Rey J.Y., Ndiaye S., Diedhiou P.M., Ba C.T., Diatta P., Seasonality and range of fruit fly (Diptera: Tephritidae) host plants in orchards in Niayes and the Thiès Plateau (Senegal). Fruits 67 (2012) 311-331.

[3] Ndiaye O., Interactions plantes hôtes, mouches des fruits et parasitoïdes dans les Niayes et en Basse Casamance, Université Cheikh Anta Diop, Dakar, Senegal, Thesis, 2014, 105 p.

[4] Vayssières J.-F., Adandonon A., N'Diaye O., Sinzogan A., Kooymann C., Badji K., Rey J.-Y., Wharton R. A., Native parasitoids associated with fruit flies (Diptera: Tephritidae) in cultivated and wild fruit crops in Casamance, Senegal, African Entomology 20(2) (2012) 308-315.

[5] Vayssières J.-F., Wharton R., Adandonon A., Sinzogan A., Preliminary inventory of parasitoids associated with fruit flies in mangoes, guavas, cashew pepper and wild fruit crops in Benin, BioControl. 56 (2011) 35-43.

[6] Goergen G., Vayssières J.-F., Gnanvossou D., Tindo M., Bactrocera invadens (Diptera: Tephritidae), a new invasive fruit fly pest for the Afrotropical region: host plant range and distribution in West and Central Africa, Env. Entomol. 40(4) (2011) 844-854.

[7] Quimio G.M., Walter G.H., Host preference and host suitability in an egg-pupal fruit fly parasitoid, Fopius arisanus (Sonan) (Hym., Braconidae), J. Appl. Entomol. - Z. Angewandte Entomol. 125(3) (2001) 135-140.

[8] Mohamed S.A., Ekesi S., Hanna R., Old and new hostparasitoid associations: parasitization of the invasive fruit fly Bactrocera invadens (Diptera: Tephritidae) and five other African fruit fly species by Fopius arisanus, an Asian opiine parasitoid, Biocontrol Sci. Technol. 10 (2010) 183-196.

[9] Haramoto F.H., Bess H.A., Recent studies on the abundance of the Oriental and Mediterranean fruit flies and the status of their parasites, Proc. Hawaiian Entomol. Soc. 20 (1970) 551-566.

[10] Wong T.T.Y., Mochizuki N., Nishimoto J.I., Seasonal abundance of parasitoids of the Mediterranean and Oriental fruit flies (Diptera: Tephritidae) in the Kula area of Maui, Hawaiian Env. Entomol. 13(1) (1984) 140-145.

[11] Qureshi Z.A., Siddiqui Q.H., Hussain T., Field evaluation of various dispensers for methyl eugenol, an attractant of Dacus zonatus, J. Appl. Entomol. 113 (1992) 365-367.

[12] Irvine F.R., Woody plants of Ghana, with special reference to their uses. Oxford University Press, London, 1961.

[13] Arbonnier M., Trees, shrubs and lianas of west african dry zones. Centre de Coopération Internationale en Recherche Agronomique pour le Développement et Museum National d'Histoire Naturelle, CIRAD-MNHN, Paris, France, 2004.

[14] Berhaut J., Flore illustrée du Sénégal. Dakar, Sénégal, Ministère du développement rural et de l'hydraulique, direction des eaux et forêts. Vol. 1, Acanthacées à Avicenniacées, p. 628; vol. 2, Balanophoracées à Composées, 696 p.; vol. 3, Connaracées à Euphorbiacées, 634 p.; vol. 4, Ficoïdées à Légumineuses, 626 p.; vol. 5, Légumineuses à Papilionacées, 658 p.; vol. 6, Lynacées à Nymphéacées, 1971-1979, 636 p.

[15] De Meyer M., Additional notes and records on the subgenus Ceratitis (Pardalaspis) Bezzi, 1918 (Diptera: Tephritidae) Bull. Ann. la Soc. R. Belge Entomol. 134 (1998) 199-202.

[16] De Meyer M., Revision of the subgenus Ceratitis (Ceratalaspis) Hancock (Diptera: Tephritidae) Bull. Entomol Res 88 (1998) 257-290.

[17] De Meyer M., Freidberg A., Revision of the subgenus Ceratitis (Pterandrus) Bezzi (Diptera: Tephritidae), Israel J. Entomol. 35-36 (2005/6)197-315. 
[18] SAS, The SAS System for Windows, version 9.1 computer program. SAS, Cary (NC) (2003).

[19] Harris E. J., Bautista R. C., Vargas R. I., Jang E. B., Eitam A., Leblanc L., Suppression of melon fly (Diptera: Tephritidae) populations with releases of Fopius arisanus and Psyttalia fletcheri (Hymenoptera: Braconidae) in North Shore Oahu, HI, USA. Electronic Table of Contents (ETOC) (United Kingdom) (2010).

[20] Wharton R.A., Trostle M.K., Messing R.H., Copeland R.S., Kimani-Njogu S.W., Lux S., Overholt W.A., Mohamed S., Sivinski J., Parasitoids of medfly, Ceratitis capitata, and related tephritids in Kenyan coffee: a predominantly koinobiont assemblage, Bull. Entomol. Res. 90 (2000) 517-526.

[21] Lopez M., Sivinski J., Rendon P., Holler T., Bloem K., Copeland R., Trostle M., Aluja M., Colonization of Fopius ceratitivorus, a newly discovered African egg-pupal parasitoid (Hymenoptera: Braconidae) of Ceratitis capitata (Diptera: Tephritidae), Flam. Entomol. 86 (2003) 53-60.

[22] Wang X.G., Bokonon-Ganta A.H., Ramadan M.M., Messing R.H., Egg-larval opiine parasitoids (Hym., Braconidae) of tephritid fruit fly pests do not attack the flowerhead-feeder Trupanea dubautiae (Dipt., Tephritidae) J. Appl. Entomol. 128 (9-10) (2004) 716-722.

[23] Bokonon-Ganta A.H, Ramadan M.M., Wang X.G., Messing R.H., Biological performance and potential of Fopius ceratitivorus (Hymenoptera: Braconidae), an egg-larval parasitoid of tephritid fruit flies, newly imported to Hawaii Biol. Control 33 (2005) 238-247.

[24] Steck G.J., Gilstrap F.E., Wharton R.A., Hart W.G., Braconid parasitoids of Tephritidae (Diptera) infesting coffee and other fruits in West-Central Africa, Entomophaga 31 (1986) 59-67.

[25] Mohamed S.A., Overholt W.A., Wharton R.A., Lux S.A., Eltoum E.M., Host specifi city of Psyttalia cosyrae (Hymenoptera: Braconidae) and the effect of different host species on parasitoid fitness, Biol. Control 28 (2003) 155-163.

[26] Mohamed S.A., Overholt W.A., Wharton R.A., Lux S.A., Effect of temperature on developmental time and longevity of Psyttalia cosyrae (Hymenoptera: Braconidae), Biocontrol Sci. Technol. 16 (2006) 7-8.

[27] Copeland R.S., Wharton R.A., Luke Q., De Meyer M., Lux S.A., Zenz N., Machera P., Okumu, M., Geographic distribution, host fruits, and parasitoids of African fruit fly pests Ceratitis anonae, Ceratitis cosyra, Ceratitis fasciventris, and Ceratitis rosa (Diptera: Tephritidae) in Kenya, Ann. Entomol. Soc. Am. 99 (2006) 261-278.

[28] Copeland R.S., Luke Q., Wharton R.A., Insects reared from wild fruits of Kenya. J. East African Natural History 98 (2009) 11-66.

[29] Canale A., Effect of parasitoid/host ratio on superparasitism of Ceratitis capitata (Wiedemann) larvae (Diptera, Tephritidae) by Opius concolor Szépligeti (Hymenoptera, Braconidae), Frustula entomologica 21 (1998) 137-148.

[30] Raspi A., Canale A., Effect of superparasitism on Ceratitis capitata (Wiedemann) (Diptera Tephritidae) second instar larvae by Psyttalia concolor (Szépligeti) (Hymenoptera, Braconidae), Redia 83 (2000) 123-131.

[31] Wharton R.A., Gilstrap F.E., Key to and status of opiine braconid (Hymenoptera) parasitoids used in biological control of
Ceratitis and Dacus s.l. (Diptera: Tephritidae), Ann. Entomol. Soc. Am. 76 (1983) 721-742.

[32] Wharton R.A., Changes in nomenclature and classification of some opiine Braconidae (Hymenoptera), Proc. Entomol. Soc. Wash. 89 (1987) 61-73.

[33] Roux E., Clain C., Souvignet J., Longévité et fécondité des femelles de Fopius arisanus, parasitoïde de mouches des fruits, et lâchers en verger de manguiers à la Réunion, AFPP $8^{\mathrm{e}}$ conférence internationale sur les ravageurs en agriculture Montpellier, 22-23 octobre 2008, (2008) 407-414.

[34] Eitam A., Vargas R.I., Host habitat preference of Fopius arisanus (Hymenoptera: Braconidae), a parasitoid of tephritid fruit flies, Ann. Entomol. Soc. Am. 100(4) (2007) 603-608.

[35] Ekesi S., Development and implementation of a sustainable IPM program for major mango pests and opportunity for improving market and processing information in sub-Saharan Africa. Progress Report. Deutsche Gesellschaft für Technische Zusammenarbeit (GTZ) GmbH, Eschborn, Germany (2010).

[36] Snowball B.V., Lukins R.G., Status of introduced parasites of Queensland fruit fly (Strumeta tryoni), 1960-1962, Austr. J. Agric. Res. 15 (1964) 586-608.

[37] Harris E.J., Bautista R.C., Effects of fruit fly host, fruit species, and host egg to female parasitoid ratio on the laboratory rearing of Biosteres arisanus. Entomologia Experimentalis et Applicata, 79 (1996) 187-194.

[38] Chinajariyawong A., Clarke A.R., Jirasurat M., Kritsaneepiboon S., Lahey H.A., Vijaysegaran S., Walter G.H., Survey of opiine parasitoids of fruit flies (Diptera: Tephritidae) in Thailand and Malaysia, The Raffles Bull. Zool. 48 (2000) 71-101.

[39] Lawrence P.O., Harris E.J., Bautista A.C., Development and reproductive biology of the egg-pupal parasite, Fopius arisanus in Anastrepha suspense, a new tephritid host. pp. 739-748. In: K. H. Tan (Ed.), Area-wide control of fruit flies and other insect pests, Penerbit Universiti Sains Malaysia, 2000, 780 p.

[40] Calvitti M., Antonelli M., Moretti R., Bautista R.C., Oviposition response and development of the egg-pupal parasitoid Fopius arisanus on Bactrocera oleae, a tephritid fruit fly pest of olive in the Mediterranean basin, Entomol. Exp. Appl. 102 (2002) $65-73$.

[41] Zenil M., Liedo P., Williams T., Valle J., Cancino J., Montoya P., Reproductive biology of Fopius arisanus (Hymenoptera: Braconidae) on Ceratitis capitata and Anastrepha spp. (Diptera: Tephritidae), Biol. Control 29 (2004) 169-178.

[42] Carmichael A.E., Wharton R.A., Clarke A.R., Opiine parasitoids (Hymenoptera: Braconidae) of tropical fruit flies (Diptera: Tephritidae) of the Australian and South Pacific region, Bull. Entomol. Res. 95 (2005) 545-569.

[43] Rousse P., Gourdon, F., Quilici, F., Host specificity of the egg pupal parasitoid Fopius arisanus (Hymenoptera: Braconidae) in La Reunion, Biol. Control. 37 (2006) 284-290.

[44] Adandonon A., Vayssières J.-F., Sinzogan A., Van Mele P., Density of pheromone sources of the weaver ant Oecophylla longinoda (Hymenoptera Formicidae) affects oviposition behaviour and damage by mango fruit flies (Diptera Tephritidae), Int. J. Pest Manag. 55 (2009) 285-292. 